\title{
FAKTOR DETERMINAN ANEMIA PADA WANITA DEWASA USIA 23-35 TAHUN
}

\author{
Erizka Marwita Triyonate, Apoina Kartini* \\ Program Studi Ilmu Gizi Fakultas Kedokteran Universitas Diponegoro \\ Jl.Dr.Sutomo No.18, Semarang, Telp (024) 8453708, Email : gizifk@undip.ac.id
}

\begin{abstract}
Background: One of nutritions problem often occurs to adult women is anemia. Anemia can be caused by inadequate intake of nutrients or oven obesity. Obesity is related to anemia because the heaped fat in adipose tissue can lower the absorption of iron. Objecttive of this research is to define the determinant factor of anemia in 23-35 years old adult women.

Method: Research was done with cross sectional design in RW 03, 04, and 05 of Kelurahan Ngaliyan Semarang. Subjects are 62 adult women of 23-35 years old who were chosen by consecutive sampling. Hemoglobin level was measured with cyanmethemoglobin, digital scale for body weight, and microtoise forbody height. Protein, iron, vitamin $C$, vitamin B12, folate, and zinc intake measured by using semi quantitative food frequency questionnaire (FFQ), and calculated with nutrisoft. Bivariate analysis test was held with correlation method.

Result: There are 31 subjects with obesity (50\%) and 9.7\% have anemia. There were 40.3\% adult women have inadequate folate intake, while protein, vitamin $C$, vitamin B12, folate, iron, and zinc intake were adequate. Bivariate analysis showed no significant correlation of nutritional status according to BMI, protein, vitamin $C$, folate, vitamin B12, zinc intake to anemia in adult women $(p=>0.05)$. There was significant correlation of iron intake with anemia $(p<0.05)$.

Conclusion: Iron intake is a determinant factor of anemia in 23-35 years old adult women.

Keywords: anemia, obesity, adult women, nutritional status, nutrient intake
\end{abstract}

\section{ABSTRAK}

Latar Belakang : Salah satu masalah gizi yang biasa dialami wanita dewasa adalah anemia. Anemia dapat disebabkan oleh asupan zat gizi yang kurang maupun karena obesitas. Obesitas berkaitan dengan anemia karena penimpunan lemak di jaringan adiposa dapat menurunkan penyerapan zat besi. Tujuan penelitian adalah untuk mengetahui faktor determinan anemia pada wanita dewasa usia 23-35 tahun.

Metode : Penelitian dilakukan di RW 03,04, dan 05 Kelurahan Ngaliyan Semarang dengan desain penelitian crosssectional. Subjek 62 wanita dewasa usia 23-35 tahun yang dipilih secara consecutive sampling. Kadar hemoglobin diukur menggunakan metode Cyanmethemoglobin, pengukuran berat badan dengan menggunakan timbangan injak digital dan tinggi badan menggunakan microtoise. Asupan protein, iron, vitamin $C$, vitamin B12, folat dan seng diperoleh dengan metode FFQ (Food Frequency Questionaire) Semi Kuantitatif kemudian dihitung dengan nutrisoft. Analisis bivariat menggunakan uji korelasi.

Hasil: Responden yang obesitas sebanyak 31 orang (50\%), dan terdapat kejadian anemia sebanyak 9,7\%. Sebanyak 40,3\% wanita dewasa yang asupan folat kurang dari kebutuhan, sedangkan asupan protein, vitamin C, vitamin B12, folat, besi dan seng sebagian besar sudah dalam kategori cukup. Hasil analisis bivariat menunjukkan tidak ada korelasi bermakna antara status gizi menurut IMT, asupan protein, vitamin C, folat, vitamin B12, dan seng dengan kejadian anemia pada wanita dewasa $(p=>0,05)$. Ada korelasi yang bermakna antara asupan zat besi dengan kejadian anemia $(p<0,05)$.

Simpulan : asupan zat besi merupakan faktor determinan anemia pada wanita dewasa usia 23-35 tahun

Kata Kunci : anemia, obesitas, wanita dewasa, status gizi, asupan zat gizi

\section{PENDAHULUAN}

Anemia sering terjadi di negara berkembang (developing countries) terutama pada kelompok dewasa yaitu wanita usia subur (WUS) ${ }^{1}$ Pada populasi 3800 juta orang di Negara sedang berkembang terdapat $36 \%$ menderita anemia. Hal ini disebabkan karena tubuh manusia mempunyai kemampuan yang terbatas dalam menyerap kandungan besi dalam zat gizi makanan. ${ }^{2}$

Wanita biasanya sangat memperhatikan bentuk tubuh, sehingga banyak yang membatasi atau memiliki pantangan terhadap makanan. ${ }^{3}$
Ketidakseimbangan asupan gizi seperti zat besi dapat menjadi penyebab anemia karena wanita mengalami menstruasi setiap bulan sehingga membutuhkan asupan zat besi yang banyak. Asupan zat besi pada makanan kurang menyebabkan cadangan besi dalam tubuh banyak yang dibongkar sehingga dapat mempercepat terjadinya anemia. ${ }^{3}$ Anemia dapat menyebabkan cepat lelah, konsentrasi menurun dan menurunkan daya tahan tubuh sehingga mudah terkena infeksi. Anemia yang terjadi pada wanita usia subur dapat 
menyebabkan bertambahnya resiko kejadian bayi dengan berat badan lahir rendah. ${ }^{4}$

Penyebab anemia bukan saja dari defisiensi besi tetapi apabila ditemukan prevalensi tinggi maka defisiensi besi tetap menjadi faktor utamanya. Penelitian di Meksiko menunjukkan sebesar 59,6\% wanita dewasa obesitas usia18-50 tahun terdapat hubungan obesitas dengan kejadian anemia. ${ }^{5}$ Menurut Riskesdas 2013, angka anemia pada wanita usia subur (WUS) sebesar 32,9\%. ${ }^{6}$ Prevalensi anemia di Jawa Tengah sebesar $57,7 \% .^{7}$ Hal ini mengindikasikan anemia masih menjadi masalah kesehatan di Indonesia terutama di Jawa Tengah. ${ }^{8}$

Obesitas berkaitan dengan anemia karena penimbunan lemak di jaringan adiposa dapat menurunkan penyerapan zat besi. ${ }^{5}$. Obesitas berhubungan dengan terjadinya peningkatan inflamasi sistemik. Penelitian di Amerika 2008 menunjukkan bahwa jaringan lemak melepaskan berbagai macam sitokin yang menyebabkan inflamasi sistemik yang berhubungan dengan patogenesis penyakit metabolik dan penyakit degeneratif yang terjadi pada obesitas. Salah satu sitokin yang dilepaskan jaringan lemak ke dalam sirkulasi portal yaitu interleukin-6 yang akan menstimulasi hati untuk memproduksi acute phase reactan yang dilepaskan hati karena perangsangan interleukin-6 yaitu hepsidin (25 amino acid peptide).${ }^{9}$ Hormon hepsidin adalah sebuah peptida atau protein kecil yang dihasilkan di hati dan mengatur kadar zat besi dalam tubuh. Hepcidin menghambat penyerapan besi dari makrofag, karena hepsidin langsung mengikat ferroportin dan menghambat aktivitas fungsionalnya. Hepsidin menghambat penyerapan besi di eritrosit dan juga berinteraksi dengan transmembrane zat besi exporter ferropotin untuk menghambat pelepasan feritin dari makrofag sehingga kadar feritin di jaringan tetap tinggi. ${ }^{9}$

Timbunan lemak pada hati dapat memicu pembentukan peroksida lipid yang pada akhirnya akan mempengaruhi proses metabolisme besi sehingga akan terjadi radikal bebas. Hal ini menyebabkan sintesis $\mathrm{Hb}$ tidak dapat berjalan dengan sempurna. Pada tahap akhir, hemoglobin menurun jumlahnya dan eritrosit mengecil sehingga dapat terjadilah anemia.$^{9}$ Di samping itu sitokin terutama TNF- $\alpha$ yang dilepaskan selama proses inflamasi juga akan berpengaruh pada regulasi feritin, yaitu akan meningkatkan penghancuran feritin di makrofag. Pada peneliti lain juga dikatakan bahwa leptin yang merupakan adipokin yang dihasilkan oleh jaringan lemak juga berperan penting untuk mestimulasi pengeluaran hepsidin pada penderita obesitas. ${ }^{10}$

Penelitian pendahuluan didapatkan Kelurahan Ngaliyan RW 03,04,10 didapatkan prevalensi obesitas sebesar $40 \%$ dari 30 orang responden. Penelitian tentang hubungan obesitas dengan kejadian anemia pada wanita dewasa usia 23-35 tahun masih jarang dilakukan karena wanita dewasa usia 23-35 rentan mengalami anemia. Berdasarkan uraian di atas peneliti tertarik meneliti faktor determinan anemia pada wanita dewasa usia 23-35 tahun.

\section{METODE PENELITIAN}

Penelitian ini dilakukan pada wanita dewasa usia 23-35 tahun di RW 03, 04, dan 05 Kelurahan Ngaliyan Semarang pada bulan Oktober 2014 dan termasuk lingkup gizi masyarakat dengan desain cross sectional. Jumlah sampel sebanyak 62 sampel yang dipilih secara consecutive sampling dimana populasi dikelompokkan berdasarkan umur diantara 23-35 tahun yang memiliki berat badan normal dan obesitas. Pada penelitian ini sampel dan kriteria inklusi terdiri dari wanita usia 23-35 tahun di RW 03, 04, dan 05 Kelurahan Ngaliyan Semarang yang bersedia menjadi responden, tidak sedang mengkonsumsi suplemen tambah darah, dan tidak sedang dalam keadaan menstruasi. Variabel dependen adalah kejadian anemia pada wanita dewasa. Variabel independen adalah status gizi, asupan protein, vitamin $\mathrm{C}$, folat, vitamin B12, zat besi dan seng wanita dewasa.

Data yang dikumpulkan dalam penelitian ini adalah identitas responden, data antropometri, kadar hemoglobin, asupan protein, vitamin $\mathrm{C}$, folat, vitamin B12, zat besi dan seng. Usia didapatkan dari selisih antara tahun penelitian dengan tahun kelahiran sesuai formulir yang telah diisi responden. Berat badan dan tinggi badan responden didapatkan dari pengukuran langsung satu kali saat melakukan penelitian. Pengukuran berat badan dengan menggunakan timbangan injak digital kapasitas 150 $\mathrm{kg}$ dan tingkat ketelitian $0,1 \mathrm{~kg}$. Pengukuran tinggi badan menggunakan microtoise kapasitas $200 \mathrm{~cm}$ dengan ketelitian $0,1 \mathrm{~cm}$. Status gizi wanita dewasa ditentukan dengan menghitung nilai nilai IMT menurut WHO 2005 yang dikategorikan menjadi normal $\left(18,5-22,9 \mathrm{~kg} / \mathrm{m}^{2}\right)$ dan obesitas $\left(>25 \mathrm{~kg} / \mathrm{m}^{2}\right)$.

Kejadian anemia pada wanita dewasa didefinisikan sebagai suatu keadaan dimana menurunnya kadar hemoglobin $(\mathrm{Hb})$ di dalam darah sehingga tidak dapat memenuhi fungsinya yang diukur menggunakan metode Cyanmethemoglobin. 
Pengambilan darah dilakukan oleh seorang analis langsung dianalisis di Laboratorium "A" Swasta di Semarang. Hasilnya dikategorikan menjadi anemia $(\mathrm{Hb}<12 \mathrm{mg} / \mathrm{dL})$ dan tidak anemia $(\mathrm{Hb} \geq 12$ $\mathrm{mg} / \mathrm{dL})$.

Asupan protein, vitamin $\mathrm{C}$, folat, vitamin B12, zat besi dan seng bersumber dari makanan yang diukur dengan metode FFQ (Food Frequency Questionaire) Semi Kuantitatif dalam rentang waktu 1 bulan, kemudian dihitung menggunakan nutrisoft. Batas kebutuhan pada wanita dewasa menurut $\mathrm{AKG}$ sebagai berikut asupan vitamin $\mathrm{C}$ $75 \mathrm{mg}$, asupan folat $400 \mathrm{mg}$, asupan vitamin B12 $2,4 \mathrm{mcg}$, asupan zat besi $26 \mathrm{mg}$ dan asupan seng $10 \mathrm{mg}$.

Data yang diperoleh kemudian dianalisis menggunakan program komputer. Analisis univariat dilakukan untuk mengidentifikasi usia responden, berat badan, tinggi badan, nilai IMT, kadar hemoglobin, asupan protein, vitamin C, folat, vitamin B12, zat besi dan seng. Analisis bivariat dengan uji Korelasi untuk mengetahui hubungan obesitas dengan kejadian anemia pada wanita dewasa usia 23-35 tahun.

\section{HASIL PENELITIAN}

Karakteristik responden

Jumlah sampel dalam penelitian ini adalah 62 orang. Berdasarkan nilai IMT menunjukkan status gizi responden dengan kategori normal sebanyak 31 orang (50\%) dan obesitas sebanyak 31 orang $(50 \%)$. Hasil perhitungan asupan protein, vitamin $\mathrm{C}$, folat, vitamin $\mathrm{B} 12$, zat besi dan seng diketahui bahwa sebanyak 40,3\% wanita yang asupan folat kurang dari kebutuhan, sedangkan asupan protein, vitamin $\mathrm{C}$, vitamin B12, zat besi dan seng sebagian besar sudah dalam kategori cukup. Berikut adalah tabel karekteristik responden

Tabel 1. Tabel karakteristik responden

\begin{tabular}{|c|c|}
\hline Variabel & n(\%) \\
\hline \multicolumn{2}{|l|}{ Status gizi } \\
\hline normal & $31(50 \%)$ \\
\hline - obesitas & $31(50 \%)$ \\
\hline \multicolumn{2}{|l|}{ Kejadian anemia } \\
\hline - normal & $56(90,3 \%)$ \\
\hline - $\quad$ anemia & $6(9,7 \%)$ \\
\hline \multicolumn{2}{|l|}{ asupan protein } \\
\hline$-\quad$ cukup $(\geq 100 \%$ AKG) & $50(80,6 \%)$ \\
\hline - $\quad$ kurang $(<100 \%$ AKG $)$ & $12(19,4 \%)$ \\
\hline \multicolumn{2}{|l|}{ asupan vitamin $\mathrm{c}$} \\
\hline - $\quad$ cukup $(\geq 100 \%$ AKG) & $61(98,4 \%)$ \\
\hline - $\quad$ kurang $(<100 \%$ AKG $)$ & $1(1,6 \%)$ \\
\hline \multicolumn{2}{|l|}{ asupan folat } \\
\hline - $\quad$ cukup $(\geq 100 \%$ AKG) & $37(59,7 \%)$ \\
\hline - $\quad$ kurang $(<100 \%$ AKG) & $25(40,3 \%$ \\
\hline \multicolumn{2}{|l|}{ asupan vitamin B12 } \\
\hline$-\quad \operatorname{cukup}(\geq 100 \% \mathrm{AKG})$ & $61(98,4 \%)$ \\
\hline - $\quad$ kurang $(<100 \%$ AKG $)$ & $1(1,6 \%)$ \\
\hline \multicolumn{2}{|l|}{ asupan zat besi } \\
\hline - $\quad$ cukup $(\geq 100 \% \mathrm{AKG})$ & $54(87,1 \%)$ \\
\hline - $\quad$ kurang $(<100 \%$ AKG $)$ & $8(12,9 \%)$ \\
\hline \multicolumn{2}{|l|}{ asupan seng } \\
\hline - $\quad$ cukup $(\geq 100 \%$ AKG) & $41(66,1 \%)$ \\
\hline - $\quad$ kurang $(<100 \%$ AKG $)$ & $21(33,9 \%)$ \\
\hline
\end{tabular}

Faktor Determinan Anemia Pada Wanita Dewasa Dilihat dari kadar hemoglobin menunjukan bahwa kadar hemoglobin terendah 10,1 gram/dL dan tertinggi 14,5 gram/dL Dari analisis menggunakan uji korelasi diperoleh nilai $\mathrm{p}$ zat besi $<0,05$ sehingga dapat disimpulkan bahwa terdapat korelasi yang bermakna antara asupan zat besi dan kadar $\mathrm{Hb}$ pada wanita dewasa.

Tabel 2 Hubungan variabel bebas dengan kadar $\mathbf{H b}$

\begin{tabular}{ccc}
\hline Variabel & $\mathbf{r}$ & $\mathbf{p}$ \\
\hline Asupan protein & $-0,093$ & $0,471^{\mathrm{a}}$ \\
\hline Asupan vitamin C & 0,186 & $0,147^{\mathrm{b}}$ \\
\hline
\end{tabular}




\begin{tabular}{ccc} 
Asupan folat & 0,062 & $0,634^{\mathrm{a}}$ \\
\hline Asupan vitamin B12 & $-0,198$ & $0,122^{\mathrm{b}}$ \\
\hline Asupan zat besi & 0,369 & $0,003^{\mathrm{a}}$ \\
\hline Asupan seng & $-0,155$ & $0,299^{\mathrm{b}}$ \\
\hline status gizi menurut IMT & 0,135 & $0,294^{\mathrm{b}}$ \\
\hline
\end{tabular}

a.pearson

b.spearman

\section{PEMBAHASAN}

$\begin{array}{cccr}\text { Status } & \text { gizi } & \text { merupakan } & \text { keadaan } \\ \text { keseimbangan } & \text { antara } & \text { pemasukan } & \text { dengan }\end{array}$ pengeluaran energi dalam tubuh. ${ }^{11}$ Pada penelitian ini wanita dewasa yang mengalami anemia sebanyak 6 orang $(9,7 \%)$, obesitas sebanyak 31 orang (50\%). Sebagian besar asupan zat gizi responden (protein, vitamin $\mathrm{C}$, folat, vitamin $\mathrm{B} 12$, zat besi, dan seng) dalam kategori cukup. Pola konsumsi sudah cukup baik dengan konsumsi asupan protein sumber hewani seperti telur ayam , hati ayam, dan ikan. Buah-buahan sumber vitamin $\mathrm{C}$ yang sering dikonsumsipun beragam seperti buah jeruk dan pisang. Sumber folat seperti sayuran hijau juga sering dikonsumsi oleh responden. Makanan seafood sumber vitamin B12 dan seng yang sering dikonsumsi seperti ikan laut dan daging.

Berdasarkan uji statistik asupan protein berhungan dengan kadar hemoglobin. Protein berperan penting dalam transportasi zat besi dalam tubuh. Kurangnya asupan protein akan mengakibatkan transportasi zat besi terhambat sehingga akan terjadi defisiensi besi. Absorpsi besi yang terjadi di usus halus dibantu oleh alat angkut protein yaitu transferin dan feritin. Transferin mengandung besi berbentuk ferro yang berfungsi mentranspor besi ke sumsum tulang untuk pembentukkan hemoglobin. ${ }^{12}$. Hasil penelitian ini tidak sejalan dengan penelitian di Brazil tahun 2005 yang menunjukkan bahwa kekurangan protein dapat mengakibatkan anemia. ${ }^{13}$

Asupan vitamin $\mathrm{C}$ juga tidak terdapat hubungan setelah dilakukan uji statistik. Vitamin C membantu mereduksi besi feri menjadi fero dalam usus halus sehingga mudah diabsorbsi. Vitamin $\mathrm{C}$ menghambat pembentukan hemosederin yang sukar dimobilisasi untuk membebaskan besi bila diperlukan. Absorbsi besi dalam bentuk nonhem meningkat empat kali lipat bila ada vitamin $\mathrm{C}$. Vitamin $\mathrm{C}$ berperan dalam memindahkan besi dari transferin di dalam plasma 34 ke feritin hati. Hasil ini tidak sejalan dengan penelitian di India yang menyatakan adanya hubungan kekurangan vitamin $\mathrm{C}$ dengan kejadian anemia pada wanita dewasa. Asupan makanan dari sumber vitamin $\mathrm{C}$ bersama dengan sumber yang kaya zat besi seperti konsumsi buah-buahan dapat meningkatkan penyerapan besisecara signifikan. ${ }^{14}$

Vitamin B12 dan asam folat berfungsi sebagai koenzim dalam pembentukan DNA. Defisiensi folat terkait anemia makrositik karena kurangnya DNA. Hasil penelitian menunjukkan tidak ada hubungan anemia dengan asupan folat. Hasil tersebut tidak sejalan dengan penelitian di Lebanese tahun 2005 dan di Mexican tahun 2002 yang menunjukkan bahwa kekurangan folat pada wanita tidak dapat mengakibatkan anemia. Pada responden konsumsi sumber seperti telur ayam frekuensinya sering ${ }^{1516}$.

Zat besi penting untuk sintesis hemoglobin oleh eritrosit. Hemoglobin tersusun dari suatu protein yaitu globin. Globin terdiri dari empat rantai polipeptida yang melekat pada empat gugus hem yang mengandung besi. ${ }^{17}$ Berdasarkan uji statistik terdapat hubungan yang bermakna antara anemia dan asupan zat besi. Hasil tersebut sejalan dengan penelitian di Nunavik tahun 2004 yang menunjukkan bahwa anemia yang dialami wanita reproduktif adalah anemia defisiensi besi. ${ }^{18}$ Kebutuhan yang tinggi akan besi pada wanita terutama disebabkan kehilangan zat besi selama menstruasi. ${ }^{19}$ Konsumsi sayur-sayuran sumber zat besi dapat mengurangi resiko terjadinya anemia.

Seng adalah mineral penting yang dapat mengurangi terjadinya anemia. Hasil penelitian menunjukkan tidak ada hubungan anemia dengan asupan seng sehingga hasil tersebut tidak sejalan dengan penelitian di Nepal tahun 2009 yang menunjukkan bahwa kekurangan seng pada wanita reproduktif dapat mengakibatkan anemia. ${ }^{20} \mathrm{Hal}$ ini dikarenakan asupan seng yang dikonsumsi responden cukup. Makanan sumber seng yang sering dikonsumsi adalah kerang, ikan laut dan daging ayam.

Status gizi adalah suatu ukuran mengenai kondisi tubuh seseorang yang dapat dilihat dari makanan yang di konsumsi dan penggunaan zat-zat gizi didalam tubuh. Klasifikasi IMT berdasarkan populasi asia adalah $<18,5(\mathrm{~kg} / \mathrm{m})$ underweight, $18,5-22,9 \quad(\mathrm{~kg} / \mathrm{m}) \quad$ normal, $23-24,9 \quad(\mathrm{~kg} / \mathrm{m})$ overweight, $25-29,9(\mathrm{~kg} / \mathrm{m})$ obese 1 , dan $\geq 30$ $(\mathrm{kg} / \mathrm{m})$ obese 2 . Hasil penelitian menunjukkan tidak 
ada hubungan anemia dengan status gizi sehingga hasil tersebut tidak sejalan dengan penelitian di Meksiko tahun 2011 bahwa wanita dewasa normal dan obesitas dapat menyebabkan anemia. ${ }^{5}$ Obesitas berkaitan dengan anemia karena penimbunan lemak di jaringan adiposa dapat menurunkan penyerapan zat besi. ${ }^{5}$. Timbunan lemak pada hati dapat memicu pembentukan peroksida lipid yang pada akhirnya akan mempengaruhi proses metabolisme besi sehingga akan terjadi radikal bebas. Hal ini menyebabkan sintesis $\mathrm{Hb}$ tidak dapat berjalan dengan sempurna. Pada tahap akhir, hemoglobin menurun jumlahnya dan eritrosit mengecil sehingga dapat terjadilah anemia.$^{9}$

\section{SIMPULAN}

Wanita dewasa anemia sebanyak 9,7\%. Asupan zat besi berhubungan dengan kadar hemoglobin.

\section{SARAN}

Wanita dewasa perlu meningkatkan konsumsi zat besi terutama saat menstruasi, dan mencukupi kebutuhan asupan protein, vitamin C, folat, vitamin B12, zat besi, seng, kobalt, dan tembaga pada kebutuhan sehari-hari.

\section{DAFTAR PUSTAKA}

1. Departemen gizi dan kesehatan masyarakat FKMUI. Gizi dan Kesehatan Masyarakat. Jakarta : PT Raja Grafindo Persada. hal 200-201； 205-206. 2007

2. Bakta IM, Pendekatan Terhadap Pasien Anemia. In : Sudoyo AW, Bambang Setiyohadi, Idrus Alwi, Marcellus Simadibrata K, Siti Setiati, editors. Buku Ajar Ilmu Penyakit Dalam. edisi IV, jilid II. Jakarta Pusat: Pusat Penerbitan Il mu Penyakit Dalam FK UI; 2006.p.622-623.

3. Agus ZAN. Pengaruh Vitamin C Terhadap Absorpsi Zat Besi pada Ibu Hamil Penderita Anemia. In : MEDIKA Jurnal Kedokteran dan Farmasi. Vol. XXX; 2004.p. 496 - 499.

4. National Anemia Action Council. Anemia in Adolescents : The Teen Scene. 2009 January 14. Available from: http://www.anemia.org. Cited 2014 March 9

5. Ana C Cepeda-Lopez et al. 2011. Sharply higher rates of iron deficiency in obese Mexican women and children are predicted by obesity-related inflammation rather than by differences in dietary iron intake. Am J Clin Nutr 2011;93:975-83

6. Riset Kesehatan Dasar. Jakarta : Badan Penelitian Kesehatan Kementrian Kesehatan RI. 2013

7. Dinas Kesehatan Provinsi. . Kumpulan Laporan Program Gizi. 2009

8. Adnani, Hariza. Ilmu Kesehatan Masyarakat.. Yogyakarta: Nuha Medika. 2011.
9. Pereira et al. Fast-food habits, weight gain, and insulin resistance (the CARDIA study): 15-year prospective analysis. Lancet 2005 Jan 1;365:36-42

10. McClung JP, Karl JP. Iron deficiency and obesity: the contribution of inflammation and diminished iron absorption. Nutr Rev 2008;67:100-

11. Supariasa. Penilaian Status Gizi. Jakarta: EGC. 2002.

12. Webb, Geoffrey P. Dietary Supplements and Functional Foods. UK: Blackwell Publishing Ltd. 2006.

13. Borelli $\mathrm{P}$ et al. Reduction of erythroid progenitors in protein-energy malnutrition . British Journal of Nutrition(2007), 97, 307-314

14. Mehnaz S, Afzal S, Khalil S, Khan Z. Impact of Iron, Folate \& Vitamin C Supplementation on The Prevalence of Iron Deficiency Anemia In Nonpregnant Females of Peri Urban Areas of Aligarh Indian Journal of Community Medicine Vol. 31, No. 3, July - September, 2006

15. Al Khatib L, Obeid O, Sibai A M, Batal M, Adra N and Hwalla N. Folate deficiency is associated with nutritional anaemia in Lebanese women of childbearing age. Public Health Nutrition: 9(7), 921-927

16. Morris M S, Jacques $\mathrm{P} F$, Rosenberg I H, and Selhub J. Folate and vitamin B-12 status in relation to anemia, macrocytosis, and cognitive impairment in older Americans in the age of folic acid fortification1-4 . Am J Clin Nutr2007;85:193-200

17. Veldman James. Anatomy and Physiology: An Easy Learner. (diterjemahkan oleh Palupi Widyastuti). Jakarta: EGC. 2004.

18. Plante $\mathrm{C}$, Blanchet $\mathrm{C}$ and $\mathrm{O}$ 'Brien $\mathrm{H} \mathrm{T}$. iron Deficiency anD anemia among Women in nunavik. Nunavik Inuit Health Survey 2004

19. Masrizal. Anemia Defisiensi Besi. Fakultas Kedokteran Universitas Andalas. Jurnal Kesehatan Masyarakat, 2007,

20. Chandyo R K et al. Zinc Deficiency Is Common among Healthy Women of Reproductive Age in Bhaktapur, Nepal. J. Nutr. 139: 594-597, 2009 